\title{
INFORMATION ABOUT THE AUTHOR
}

Tetyana Kobina - Doctor of Pedagogical Sciences, Professor, Professor of foreign languages and intercultural communication department at S. Kuznets Kharkiv National University of Economics.

Scientific interests: communicative preparation of students in higher educational institutions, formation of experience in intercultural communication of the future specialist.

\author{
УДК 81'1 : 81'22 : 81'374 +008 \\ DOI: 10.36550/2522-4077-2021-1-193-312-321
}

\author{
ХВОРОБА У ДЗЕРКАЛІ МОВИ \\ Олександр КОЛЕСНИК (Київ, Украӥна) \\ Orcid: https://orcid.org/0000-0002-1618-3804 \\ e-mail: axli@i.ua
}

КОЛЕСНИК Олександр. ХВОРОБА У ДЗЕРКАЛІ МОВИ. Мовні засоби, щзо вербалізують концепт ХВОРОБА, аналізуються з позичій міфосеміотики та лінгвоуніверсології. Особливу увагу приділено етимологічним особливостям і типологічним паралелям семантики імен концепту у різних європейських мовах. Семантика номінацій ХВОРОБИ інтерпретується з позицій лінгвоуніерсологї та М-логіки. Встановлено лінгвокогнітивне підтрунтя та визначено основні функціонально-семантичні характеристики номіначій хвороби в англомовному пісенному дискурсі.

Ключові слова: система, основа, значення, хвороба, лінгвокультура, ентропія

KOLESNYK Oleksandr. THE DISEASE CONCEPT THROUGH THE LANGUAGE MIRROR. The article analyzes language means verbalizing the concept of DESEASE. The paper suggests multi-vecrored interpretations of the concept names' etymology and highlights a number of typological parallels thus targeting certain universalia that pertain to biological systems' disorders and dusfunctions. The implemented methodology exercises the eco-centric focus of interpretations, considers irrational premises of cognition and rationalization of reality, fuzzy nature of objects and phenomena involved in multidimensional interactions, non-linear causative correlations of diverse phenomena and respective generic systems, quantum peculiarities of verbally conveyed informational clusters, enigmatic nature of systems' development at bifurcation points as well as systems' inverse fluctuations. The synthetic-analytical interpretations of the concept names' etymology allowed reconstructing the inchoative "nano-myth" that impacts the trajectories of further conceptualization and designation of disease-related phenomena. This "nano-myth' contains the idea of structural deformation (distortion or uncontrolled expansion) which triggers the systems' entropy rise, energy loss, dysfunctionality, discomfort and painful symptoms, as well as negative assessment (as either auto-diagnostics or external assessment). Semantics of respective stems suggests an explanation of traditional asspciating disease and mythic creatures. The paper introduces a folmal logical model of DISEASE as scenario / "eventive" concept. The article discusses functional-semantic roles of language signs verbalizing DISEASE in different texts in Germanic languages of diverse historic periods. The paper provides quantitative analysis of respective designation units within a customary corpus encompassing English lyrics authored by the present-day rock musicians. The units from the corpus are subjected to semantic and linguo-cognitive analysis which traces the way the DISEASE is projected onto a variety of social and cultural spheres of human existence.

Key words: system, stem, semantics, disease, liguo-culture,entropy

Постановка проблеми та аналіз останніх досліджень і публікацій.

3 огляду на глобальні трансформаційні процеси, що розгортаються у різних планах буття людства та зачіпають практично усі сфери відомої нам цивілізаційної моделі, поглиблюється низка кризових явищ, зумовлених розбіжностями між декларованими цінностями й орієнтирами (природо-центричний світогляд, здоровий спосіб життя, права людини, культурне розмаїття тощо) й реаліями (споживацько-паразитичний спосіб "господарювання", авто-деструктивний спосіб життя, викривлення і маніпуляції у сфері прав людини, глобалізація та уніфікація культур). Специфічна епідеміологічна ситуація, що склалась на планеті протягом 2019-2021 pp. і не отримала ані ефективного терапевтичного, ані превентивно-профілактичного розв'язання попри усі цивілізаційні здобутки, ресурси та технології, накладається на окреслені кризові феномени й сприяє накопиченню ентропійних характеристик усіх систем сучасної цивілізації. У цьому контексті на окрему увагу 
заслуговують вербально закодовані уявлення про сутність ХВОРОБИ. У розвідках різноманітного спрямування висвітлено зв'язок номінацій хвороб і концептів античної міфологіï (Ó Ceallaigh, 2019; Tagarelli, 2011; Trompoukis, 2007), здійснено інтерпретацію вербально окресленої у прецедентних текстах симптоматики захворювань (Ehrenkranz, 2008), розглянуто когнітивні та психологічні основи евфемістичної номінації хвороб (Jamet, 2019). Водночас, недослідженими $є$ інхоативні значення, пов'язані з інтерпретацією хвороби як біовітального, соціального та аксіологічного феномену. Відповідно, актуальними $\epsilon$ реконструкція та унівесологічно орієнтований аналіз первинних смислів, що становлять основу осмислення низки дотичних феноменів, а метою статті є багатоаспектний аналіз вербальних репрезентацій хвороби з використанням методології М-логіки.

Виклад основного матеріалу. 3 огляду на особливості міфологічно-орієнтованого семіозису, сутнісні ознаки денотатів і їхніх концептуалізованих іпостасей, закодовані у внутрішній формі мовних знаків, іконічно віддзеркалюють уявлення про "первинний стан" відповідної системи. При цьому, семантика першооснов (базових "код-онів") відповідних номінативних одиниць становить "нано-міф" як дефолтну програму функціонування системи, а також постає базовим оператором для ре-інтерпретації відповідного феномену у різні історичні епохи у відмінних контекстах (Колесник, 2013; Колесник, 2017).

Термінологічна дефініція ХВОРОБИ окреслює базові ознаки явища: "патологічний процес, який проявляється порушеннями морфології (анатомічної, гістологічної будови), обміну речовин чи / та функціонування організму (його частин) у людини / тварини" (Патофизиология: 67). Водночас, зміст власне медичного терміну на позначення хвороби (morbus) вказує на "еквіфінальний стан системи", що, втім, відрізняється від природного "перехідного процесу" (зникнення, переформатування як прояв універсальних закономірностей обміну речовини та енергіï) унаслідок порушень іiї функційних алгоритмів: лат. morbus "хвороба", morbidus "хворий, померлий" (а. morbid, ca. morbous "померлий") < mori "помирати" / "мати вигляд помираючого" < iє. "mer- "чинити шкоду, стирати", "помирати" (Pokorny: 733, 735), де смерть постає як наслідок "заспокоювання", тобто, втрати системою власного енергетичного потенціалу або ресурсів для функціонування. Значення "порушення" або"відхилення від норми" (під нормою розуміємо оптимальний стан і функціонування системи у відповідному середовищі), що викликає дискомфортний стан системи, вербалізується у а. pathology < фр. pathologie < лат. pathologia < гр. $\pi \dot{\alpha} \theta$ ऽ "страждання, журба, нещастя" < іє. *kwent(h)- "страждати" (Hofmann: 460, 478-479). Типологічно $з$ цими термінами співвідноситься більш пізнє а. disease < дфр. desaise"брак, дискомфорт, невезіння, хвороба" = des- "без"+ aise "спокій". Синонімічні номінації morbus i pathologia вказують на "системну похибку", проявлену у низці спостережуваних симптомів, що можуть отримувати негативну зовнішню оцінку.

У слов'янських мовах укр. хвороба, пол. choroba, слц. choroba, чес. choroba, укр. хворий, блр. хворы, вл., нЛ. chory, чес. chory, полаб. хӧrё, хӥӧre "гидкий, бридкий", пслов. xvorb < *suoro(*suero-) "різати, колоти, наривати, гноїтися" (пор. двн. swëran "ятритися, викликати біль", свн. swër "біль, хвороба", н. Schwär, Geschwür "болячка"), тобто "деформація, що призводить до больових відчуттів"; або < іє. *ks- / *kes- "різати" ("структурне пошкодження, фрагментація"); або < іє.*khour / kheour-; або < *guer- (ЕСУМ: (6) 168; Фасмер: (4) 232). Жодна з версій реконструкції вихідного "код-ону" не є переконливою, однак, їхнє узагальнення дозволяє вести мову про "несприятливі [негативно оцінювані] сигнали, викликані пошкодженням системи". Гіпотетично, віддалено асоційованою 3 *suero-) $е$ герм. *dwer-g- $<* d w e z-g-<* d w e s-g-$ "дурний", що є основою семантичних трансформацій, котрі вмотивували номінацію ГНОМА: "гном" "дурний" / "хворий") Ł "під впливом міфічної / ворожої істоти" (Liberman: xxxvi), при чому у семантиці першооснови синкретично поєднані ознака "викривлений" (двн. twerg, да. dweorg, дінд. dhvárati "зігнутий, пошкоджений") функціональна ознака ГНОМА "шкідник" (гел . tiachair "гном, хворий, збочений" (McBain: 366) $\rightarrow$ "джерело хвороби", пор. ототожнення хвороби 3 гномом у метричному заклятті: Wið dweorh (WD: 1), Pa com in gangan dweores sweostar "прокралася всередину гномова сестра" (WD: 12).

Подібна, але більш "прозоро" вмотивована номінація хвороби спостерігається у одиницях типу рос. болезнь, болг. болест, босн. bolest, макед. болест, серб. болест, словен. bolezen, хорв. bolest, < *bol- (ЭССЯ: 186-187) реалізована метонімічна номінація за "чуттєвою 
симптоматикою". При цьому рос. боль, укр. біль, серб., хорв. бо́́л м., словен. bot, укр. боліти, болг. болея, серб., хорв. больети, словен. boljeti, чес. boleti, пол. bolec, влуж. bolić, boleć, нлуж. boleś. (Фасмер: (1) 191) спорідн. $з$ двн. balo "згуба, прокляття, зло", дісл. bol, дфриз. balu, дсакс. balu, да. bealu "нещастя, зло", гот. balwawesei "злість", balwaweins "біль, страждання", balwjan "мучити", дісл. bolva "проклинати" < герм. *balwjan- "спричиняти страждання < *balw-"біль, страждання" < iє. *bhel- / bhol- "набухати, пухнути" (Левицкий: 89; Kroonen: 50) тобто, в основі уявлень про хворобу є "запальний процес" і викликані ним деформації та відчуття, а в більш широкому сенсі "неконтрольоване розширення, надмірна ентропія системи".

Номінації хвороби кельтськими мовами реалізують такі значення: 1) гел. galar, ірл., дірл. galar "хвороба", брет. glar, glachar, вал. galar "горе" < *galro-, можливо, спорідн. 3 дпівн. galli "вада", умбр. holtu "поганий, болючий". Водночас, можливий зв'язок з гел. gal "плакати", ірл. gul, дірл. gol, < iє. *gel-, "біль (н. Qual "біль, тортури"); однак, омонімічна одиниця гел. gal "звитяга, війна", дірл., дбрет. gal, "влада, сила, могутність", вал. gallu "військовий загін", брет. galloet, корн. gallos "сила, могутність" *galno- (лит. galiu "я можу") (McBain: 187), дозволяє реконструкцію смислу "пошкодження з больовим відчуттям як наслідок використання сили / енергії (зовнішнього силового впливу)".

2) гел. eucail "хвороба" (McBain:156), eugail "хвороба" гел. eug "смерть", ірл., eug, дірл. е́c, вал. angeu, корн., дбрет. ancou < *enku-s, *enkevo- (лат. nex "смерть"; гр. vєкvб "труп"; снск. nag "гинути" (McBain:157) здійснюють відсилку до термінального варіанту розвитку сценарію "перебіг хвороби" (у статично-потенційному стані маркують орієнтаційний контур змісту відповідного "евентивного" концепту) і типологічно співвідносяться з герм. *kring-.

Германські номінації хвороби а. sickness, норв. sykdom, дан. sygdom, ісл. sjúkdómur, нід. ziekte, фриз. sykte, шв. sjukdom (а. sick "хворий, недобрий" < да. seоc "хворий, слабкий, немічний, спотворений, мертвий, уражений", пор. дпівн. sjukr, дан. syg, дсакс. siok, дфриз. siak, снід. siec, нід. ziek, двн. sioh, н. siech "слабкий", гот. siuks "sick, ill") < герм. *seukaz "хворий" < протогерм. *seuka- <* іє. seu- / seug- / suek- / sueg- "обертати, крутити, скручувати" (Левицкий: 447). Ймовірно, * іє. seu- пов'язаний також із дісл. sott, норв. sott, шв., дан. sott, да. suht, двн. suht, гот. sauhs "хвороба", н. Sucht "пристрасть, манія", а. besot "затьмарювати розум", а також дісл. sut, норв. sūt "хвороба, горе" < герм. *suhti- (Vries: 531, 564), де "хвороба як наслідок обертання" вказує на психічний розлад. Розвиток значення "скручений" > "поганий" > "слабкий" > "хворий", що уявляється як "слабкість унаслідок деформації", аналогічний до н., нід. krank "хворий" < a. crank "згинати, слабкий", да. cranc "хворий", снід. krank "слабкий, хворий, незначний", снн. krank "слабкий, поганий, злий", свн. kranc "слабкий, поганий, незначний", двн. krank "слабкий", дфриз. kronk "слабкий, хворий", шв. krank, дісл. krangr "слабкий", свн. krangel "біда, потреба", дісл. kranga "повзти", а. cringe "гнутися", да. cringan "гинути у бою"< *kring- / krang- / krung- "гнути; вигин"(Левицкий: 331) У цьому випадку "хвороба" позначається як "втрата енергії" системою. Подібні евфемістичні номінації наявні в інших мовах, пор. укр. розм.: Дідо зовсім заслаб головою.

При типологічному зіставленні вказані значення асоціативно корелюють 3 iє. alp"маленький, слабкий" > протогерм. *alba-z, *albi-z > a. elf, да. älf, ilf, ylf"злий дух, монстр", дпівн. alfr, норв. alv, дшвед. $\ddot{l} l f$, ддан. $e l v$, дсакс. alf, снід. alf, нід. alf, свн. alf, двн. alb, нім. alp "примарна істота, помічник чорта; дурень" [Pokorny: 35], при чому слабкість та невеликий розмір істоти $\epsilon$ мотиваційною основою розвитку значень "хворобливий" ' "дурний" (пор. гел. ealbhar "нездара"< дпівн. alfr, elf [McBain: 150] і "той, що спричиняє хворобу", "шкідливий" та "злий". Відповідно, при вторинній номінацій відбувається і зворотне метонімічне перенесення "міфічна істота" $\rightarrow$ ["шкідлива" / "шкідник"] $\rightarrow$ "хвороба", що віддзеркалює уявлення про надзвичайних істот як джерело хвороб (пор. да. назву хвороби у метричному заклятті: wcetercelfadle (Wt: 1), підвид "хвороби" типу психічного розладу: н. фолк. es lag ihm (wie) ein Alp auf der Brust "це його дуже пригнічувало". Значення "втрата сили" / "енергії" як основа номінації хвороби реалізована також у ісп. enfermedad, галіс. enfermidade, a. infirmity ) < лат. infirmus "слабкий, ламкий" = in"заперечення / протилежний" + firmus "міцний, стабільний" < *dher- "тримати, підтримувати".

A. illness "хвороба", а. ill "хворий, неприйнятний, хворобливий, болючий, нещасливий" $<$ дпівн. illr "злий, поганий, важкий" 3 подальшою затемненою етимологією. При 
узагальненні версій, що вказують на спорідненості дпівн. illr та: 1) двн. ilgi < *elhila; пор. запозич. фін. elkiä "веселий, кумедний, пустотливий", ilkiä "огидний, потворний, жахливий, злий, підступний"; 2) з.в., одн. illan < *iðlan, ìđilan, да. ìdel, дсакс. ìdal, ìdil, двн. ìtal "марний, непотрібний, порожній"; 3) illan < *iðlan, ið, з розвитком значення "старанний, надмірний" > "поганий" (пор. укр. розм. що занадто - то не здраво); 4) дірл. elc "злий", дслов. lakati, лит. alkti, латв. alkt "жадати, бути голодним" < *el- "гнутися, згинатися" (Vries: 285), а також 3 урахуванням семантики герм. *iljan- "поспішати" (дсакс. ilian, снід. ilen, нід. ijlen "поспішати", двн. illan, ilen, н. eilen "поспішати" < ? *hle(i)- "йти, пересуватись", а також герм. *idojan- "пересуватись хаотично, рухатись, коливатись" < ? *hli-t-eh2 (Kroonen: 269), маємо змогу реконструювати "нано-міф": "незадовільний (оцінюваний як поганий) стан системи, викликаний неконтрольованим рухом / надмірною динамікою / нерегульованим споживанням ресурсів, що замість забезпечення функціонування системи спотворює іiі конфігурацію".

Розвиток негативних оцінних конотацій у номінацій хвороби різними мовами має наступну германську паралель: a. ailment < да. eglan "турбувати, вражати" < протогерм. *azljaz (EDME) (також джерело да. egle "огидний, потворний, болючий", гот. agls "негідний, той, що викликає сором", aglipa "труднощі, розлад", usagljan "пригнічувати ") < i.є., *agh-lo-, *agh- (1) "боятись, бути пригніченим".

Нарешті, номінації типу ісп. mal, іт. malattia, фр. maladie, mal, дфр. maladie a. malady < лат. male habitus "у поганому стані, хворобливий" < лат. male "погано", malus / mala / malum "поганий" < iє. * mel- "хибний, поганий, неправильний", при чому полісемантизм *mel- дозволяє посднання значень "хибний" > "злий" (Pokorny: 719) і "сильний, великий" > "надмірний" (лат. multus, гр. $\mu \alpha \lambda \alpha$ "багато ") (Pokorny: 720), що виявляється типологічною паралеллю до закодованого іншими основами смислу "неконтрольоване розширення системи". У свою чергу, habitus (дієпр. від habere "мати, тримати" < iє. *ghabh-, ghebh-, "давати, отримувати" (санскр. gabhasti- "рука", дірл. gaibim "я беру / маю", лит. gabana "жменя", гот. gabei "скарб", да. giefan, дпівн. gefa "давати"), що уможливлює реконструкцію смислу "набутий / переданий стан [негативно оцінюваної] деформації".

Отже, для індоєвропейських лінгвокультур притаманні універсальні уявлення про хворобу як результат структурної деформації (викривлення або неконтрольоване розширення), що призводить до збільшення рівня ентропії системи, втрати енергетичного потенціалу, дисфункційності й некомфортного стану 3 відповідними (больовими) симптомами, а також негативною оцінкою (як зовнішньою, так i, потенційно, автооцінкою). Алюзивно здійснюється відсилка до зовнішніх причин хвороби, співвіднесених з міфічними істотами. При цьому зовнішні чинники надсистемного плану здатні здійснювати лікувальну дію на систему, при чому і хвороба і людина осмислюються як об'єкти впливу, хвороба постає пацієнсом, а людина - бенефактивом: et auferam infirmitatem de medio tui._"і я заберу хворобу з-поміж вас" (Vulgate: Ex. (23) 25), infirmus, et visitastis me "я був хворий, і ти потурбувався про мене" (Vulgate: Mat.(25)-36). В абстрактно-логічному вигляді наведені значення впорядковуються так:

(1) IN SYS $\left(W^{n}\right)=\sum p\left|a^{n} b^{n} c^{n} d^{n}\right| / q^{n} ; x\left|a^{n} b^{n} c^{n} d^{n}\right| / y^{n} ; s^{n} ; t^{n}$

IF (2) W/ $/ \varsigma \sum p\left|a^{n-1} b^{n-1} c^{n-1} d^{n-1}\right|$

IF (3) W / trans $(\Delta \varepsilon) \sum \mathrm{p}\left|\mathrm{a}^{\mathrm{n}-1} \mathrm{~b}^{\mathrm{n}-1} \mathrm{c}^{\mathrm{n}-1} \mathrm{~d}^{\mathrm{n}-1}\right|$

IF (4) W / (scen $\Delta \mathrm{n}) \sum \mathrm{p}\left|\mathrm{a}^{\mathrm{n}-1} \mathrm{~b}^{\mathrm{n}-1} \mathrm{c}^{\mathrm{n}-1} \mathrm{~d}^{\mathrm{n}-1}\right|$

THEN

(5) $\sum \mathrm{p}\left|\mathrm{a}^{\mathrm{n}} \mathrm{b}^{\mathrm{n}} \mathrm{c}^{\mathrm{n}} \mathrm{d}^{\lim \rightarrow 0}\right| / \mathrm{q}^{\lim \rightarrow 0} ; \mathrm{x}^{\prime}\left|\mathrm{a}^{\Delta \mathrm{n}} \mathrm{b}^{\Delta \mathrm{n}} \mathrm{c}^{\Delta \mathrm{n}} \mathrm{d}^{\Delta \mathrm{n}}\right| / \mathrm{y}^{\prime \mathrm{n}} ; \mathrm{s}^{\prime \Delta \mathrm{n}} ; \mathrm{t}^{\prime \Delta \mathrm{n}}$

(6) $\sum \mathrm{p}\left|\mathrm{a}^{\mathrm{n}} \mathrm{b}^{\mathrm{n}} \mathrm{c}^{\mathrm{lim} \rightarrow 0} \mathrm{~d}^{\mathrm{n}}\right| / \mathrm{q}^{\lim \rightarrow 0} ; \mathrm{x}^{\prime}\left|\mathrm{a}^{\Delta \mathrm{n}} \mathrm{b}^{\Delta \mathrm{n}} \mathrm{c}^{\Delta \mathrm{n}} \mathrm{d}^{\Delta \mathrm{n}}\right| / \mathrm{y}^{\prime \prime} ; \mathrm{s}^{\Delta \mathrm{n}} ; \mathrm{t}^{\Delta \mathrm{n}}$

(7) $\sum \mathrm{p}\left|\mathrm{a}^{\mathrm{n}} \mathrm{b}^{\lim \rightarrow 0} \mathrm{c}^{\mathrm{n}} \mathrm{d}^{\mathrm{n}}\right| / \mathrm{q}^{\lim \rightarrow 0} ; \mathrm{x}^{\prime}\left|\mathrm{a}^{\Delta \mathrm{n}} \mathrm{b}^{\Delta \mathrm{n}} \mathrm{c}^{\Delta \mathrm{n}} \mathrm{d}^{\Delta \mathrm{n}}\right| / \mathrm{y}^{\prime \prime} ; \mathrm{s}^{\prime \Delta \mathrm{n}} ; \mathrm{t}^{\prime \Delta \mathrm{n}}$

(8) $\sum \mathrm{p}\left|\mathrm{a}^{\lim \rightarrow 0} \mathrm{~b}^{\mathrm{n}} \mathrm{c}^{\mathrm{n}} \mathrm{d}^{\mathrm{n}}\right| / \mathrm{q}^{\lim \rightarrow 0} ; \mathrm{x}^{\prime}\left|\mathrm{a}^{\Delta \mathrm{n}} \mathrm{b}^{\Delta \mathrm{n}} \mathrm{c}^{\Delta \mathrm{n}} \mathrm{d}^{\Delta \mathrm{n}}\right| / \mathrm{y}^{\prime \mathrm{m}} ; \mathrm{s}^{\prime \Delta \mathrm{n}} ; \mathrm{t}^{\prime \Delta \mathrm{n}}$

(9) $=$ SYS ${ }^{\lim \rightarrow 0}$

- (1) якщо система (SYS) з будь-якого світу (W) мірності (n), що включає живу істоту (p) $з$ онтологічними (a), функційними (b), аксіологічними (c) та локативними (d) ознаками, проявленими у ступені / мірності (n), яка виконує дії (q), дозволені виміром (n), а такох неживих предметів (x), з відповідними онтологічними (a), функційними (b), аксіологічними 
(c) та локативними (d) ознаками, проявленими у ступені / мірності (n), що функціонують як (y) за нормами виміру (n) у просторі (s) та часі (t), організованими за закономірностями виміру(n), (2) за умови використання базового міфологічного інтерпретаційного оператора $(\varsigma),(3)$ здійснення впливу енерго-інформаційного імпульсу певної сили $(\Delta \varepsilon)$, що трансформує систему (trans), або (4) розгортання низки варіативних сценаріїв (scen $\Delta \mathrm{n}$ ), у ході котрих будь-який параметр живої істоти $p$ погіршується у ступені $n-1$, в архітектурі біовітального ядра системи (живої істоти $p$ ) можливі (5) просторові деформації або пошкодження $\left(\mathrm{d}^{\lim \rightarrow 0}\right)$, (6) погіршення оцінки з боку кореферентних систем $\left(\mathrm{c}^{\lim \rightarrow 0}\right)$, (7) обмеження функціонального потенціалу $\left(\mathrm{b}^{\lim \rightarrow 0}\right),(8)$ атрофія сутнісних ознак або компонентів істоти $\left(\mathrm{a}^{\lim \rightarrow 0}\right)$, що у кожному випадку унеможливлюють виконання суб'єктом звичайного набору дій $\left(q^{\lim \rightarrow 0}\right)$, або анігіляція системи (SYS ${ }^{\lim \rightarrow 0}$ ).

Номінації ХВОРОБИ (НОСІЇВ ХВОРОБИ) у текстах германськими мовами різних жанрів і історичних епох (у синкретично-синтетичному розумінні - у "квантовому" просторі семіосфери, що поєднує діахронічно віддалені, але семантично нелінійно-компліментарні, вербально сконструйовані альтернативні світи) засвідчують, що відповідний феномен як об'єкт категоризаційної та мовно-семіотичної діяльності людини інтерпретований на таких системних рівнях (Колесник, 2017):

(1) рівень фізично-фізіологічний: feorhseoc fleon under fenhleoðи "[Grendel] смертельнохворий шукав прихистку на болотах" (Beowulf: 819-820), wordcwydum wundum dryhtne hyran heaðosiocum "за велінням словом його пораненого вородаря, хворого-від-війни"(Beowulf: 2753-2754), sexbennum seoc "хворий від ран, завданих мечем"(Веowulf: 2904), де -seoc / seoc це метафоричний кваліфікатор, що при сполученні з номінатором каукзатора / джерела хвороби (feorh-, heаðо- у композитах, або sexbennum у фразовій номінатемі) набуває значення"вражений у двобої" або "тяжко поранений"; Eft sona bið paet pec adl oððе ecg eafopes getweefeð "скоро трапиться так, що або хвороба або меч вкоротять твою силу", (Beowulf: 1702-1703), adl opðe iren "хвороба чи сталь [його вразить]" (Beowulf: 1847), no hine wiht $d w e l e ð$ adl ne yldo "ніяк не зашкодить йому ані хвороба, ані вік"(Beowulf: 1735-1736), де $a d l$ це дезигнатор, що позначає агенса як "антагоніста з більш / або менш потужним потенціалом, ніж у агоніста"

(2) рівень психо-емоційний: Gistas setan modes seoce "гості сиділи духом хворі", де seoce - метафоричний атрибутивний кваліфікатор, що у поєднанні 3 номінацією об'єкта атрибуції породжує значення "засмучений, пригнічений" (Beowulf: 1603-1604); vil manigen vngesunden sach man vroelîchen sît "хворі раділи" (Nibelungenlied: 268), де vngesunden дезигнатор, що позначає експерієнцера у стані емоційної трансформації;

(3) рівень ментальний: подібні номінації вживаються в академічному, науковому або криміналістичному дискурсі, пор.: Mental illness plays no part in the majority of violent crimes committed in our society. (MVMI), або у пісенному дискурсі: sick and perverted, A psycho's been unleashed (Iron Savior: Flesh);

(4) рівень соціально-адаптивний: Sjúkum kalfi "[не довіряй] хворій тварині" (Havamál: 87), де "вражений хворобою" $\epsilon$ симптомом до неадекватних "налаштувань" системи i непередбачуваних наслідків взаємодії з нею; mun ek pik við bölvi // brenna ganga,// likna ok loekna "тебе / тобі від хвороби випалю болячку, вилікую та зцілю" (Guðrúnarkviða: 39): у відносинах всередині групи хвороба визнається неприпустимою та в якості антагоніста потрапляє до сценарію ЛІКУВАННЯ, а констататор-дезигнатор bölvi вказує пацієнта; Ich werde sie ein Krankheit schenken (Rammstein, Mutter), де Krankheit - номінатор пацієнса, що в прогнозованому сценарії виконуватиме роль інструмента; Ich bin nach deiner Liebe so krank (In Extremo: Vollmond), де krank - кваліфікатор, фактитив, що вказує на результат взаємодії з істотою, що проявляе надзвичайні властивості. У сучасному розмовному англомовному дискурсі кваліфікатор sick $€$ абмівалентним і позначає як схвально-позитивну оцінку системи з боку групи ("That dribbling was sick!" у спортивному теле-коментарі як відзнака майстерного / надзвичайного виконання технічного ігрового елемента), так і негативну оцінку: sick fucking racist, you were born to be deceived (Annihilator: Never).

(5) рівень міжгрупових взаємодій: hvárts eru sóttdauðir "тих, хто помер від хвороби" (Sigrdrífumál: 33), де sótt- є дезигнатором каузатора, a sóttdauðir - номінацією пацієнта, на 
якого спрямована колективна / між групова діяльність (поховання); Contagious maladies, e.g. dragon pox, vanishing sickness, scrojungulus, etc. (Rowling: 486), де "хвороба" / типи хвороби $\epsilon$ фокусом між групової взаємодії у певному просторі (лікарня);

(6) рівень аксіологічний: die siechen vngesunden die mvsin si verklagen "[забули, що] про хворих слід піклуватись" (Nibelungenlied, 296), де vngesunden - дезигнатор бенефактива, учасника "невдалого сценарію", що відхилився від ціннісних орієнтирів; Er-at madr alls vesall, // pótt hann sé illa heill "Зовсім знедоленим ніхто не $\epsilon$, хоч він і хворий" (Havamál: 69), де номінація ХВОРОБИ становить один з полюсів діалектичної дихотомії.

(7) рівень інформаційний / "цивілізаційний": en eldr við sóttum "полум'я проти хвороби" (Havamál: 137), що демонструє універсальну опозицію "системна похибка [хвороба]" VS "енергія надсистеми", де ВОГОНЬ $($ eldr) є метафоричною міфопоетичною презентацією специфічного виду енергії, що вносить програму розвитку системи, трансльовану надсистемою (сакральною сферою, комплексом астрофізичних об'єктів значної мірності, законами природи тощо) і переформатує попередню пошкоджену конфігурацію системи.

Алюзивно зі "смертельною хворобою", попри відсутність прямої номінації, можуть співвідноситись вербалізації агенсів, представників контрарно (отже, вороже) орієнтованих систем, що впливають на цілу соціальну групу: se ðеodsceaða "пошесть людей" = вбивця, шкідник, монстр (Веowulf: 2278), або хибних аксіологічних орієнтирів: wommum gewitnad "уражений гріхами" (Beowulf: 3073). Низка когнітивних, пхихологічних (страх перед "трансформацією" і невідомим, очікування неприємних больових відчуттів, неспроможність виконувати звичні види діяльності, неестетичний вигляд і очікувані негативні оцінки представників соціальної групи) та культурно-регулятивних чинників (наприклад, традиційне уявлення про негідний варіант СМЕРТІ від старості або хвороби, транслюване у конструйованому реміфологізованому уявному світі: better to fall by the sword than to die from age or ail (Bathory: The Land) (ail - дезигнатор-каузатор), що детермінують негативне сприйняття системи у пошкодженому стані, призводять як до діахронічного розвитку евфемістичних (not doing well замість mortally ill) або дисфемістичних номінацій, вживання назв хвороби як інвективів: A plague o' both your houses! I am sped (Shakespeare: Act 3, Sc.3, 92), пов'язаних $з$ уявленнями про магічно-креативні здатності мовних знаків, а також про можливість передачі хвороби магічним (вербальним) шляхом.

Зокрема, в англомовному пісенному дискурсі XX-XXI ст. (у лінгвокреативний період існування лінгвокультур) номінації ХВОРОБИ демонструють такі риси ("користувацький" корпус з 728 пісенних текстів англомовних рок-виконавців загальним обсягом 131040 слів проаналізовано за допомогою AntConc 3.5.8).

Таб.1. Репрезентація номінацій хвороби у корпусі

\begin{tabular}{|l|l|l|l|}
\hline Ім'я концепту ХВОРОБА & Кількість & $\begin{array}{l}\text { Серед } \\
\text { кореферентів }\end{array}$ & У корпусі \\
\hline sickness & 38 & 17,3 & 0,023 \\
\hline disease & 126 & 57,2 & 0,096 \\
\hline illness & 3 & 1,36 & 0,002 \\
\hline malady & 3 & 1,36 & 0,002 \\
\hline ail & 1 & 0,01 & 0,000067 \\
\hline plague & 50 & 22,69 & 0,038 \\
\hline Разом & 221 & $\approx 100 \%$ & $\approx 0,16 \%$ \\
\hline Номінація наслідку хвороби & & & \\
\hline sick & 156 & 69,33 & 0,12 \\
\hline diseased & 16 & 7,11 & 0,01 \\
\hline plagued & 9 & 4 & 0,006 \\
\hline ill & 44 & 19,56 & 0,03 \\
\hline Разом & 225 & $100 \%$ & $\approx 0,17 \%$ \\
\hline Базовий симптом & & & \\
\hline
\end{tabular}




\begin{tabular}{|l|l|l|l|}
\hline \hline pain & 585 & 91,26 & 0,45 \\
\hline mutilation & 27 & 4,21 & 0,02 \\
\hline bleeding & 27 & 4,21 & 0,02 \\
\hline deformity & 2 & 0,32 & 0,00013 \\
\hline Paзом & 641 & $100 \%$ & $\approx 0,49 \%$ \\
\hline
\end{tabular}

Певні диспропорції помітні у кількісні репрезентації імен ХВОРОБИ і когнатів - назв відповідного стану (Рис.1).

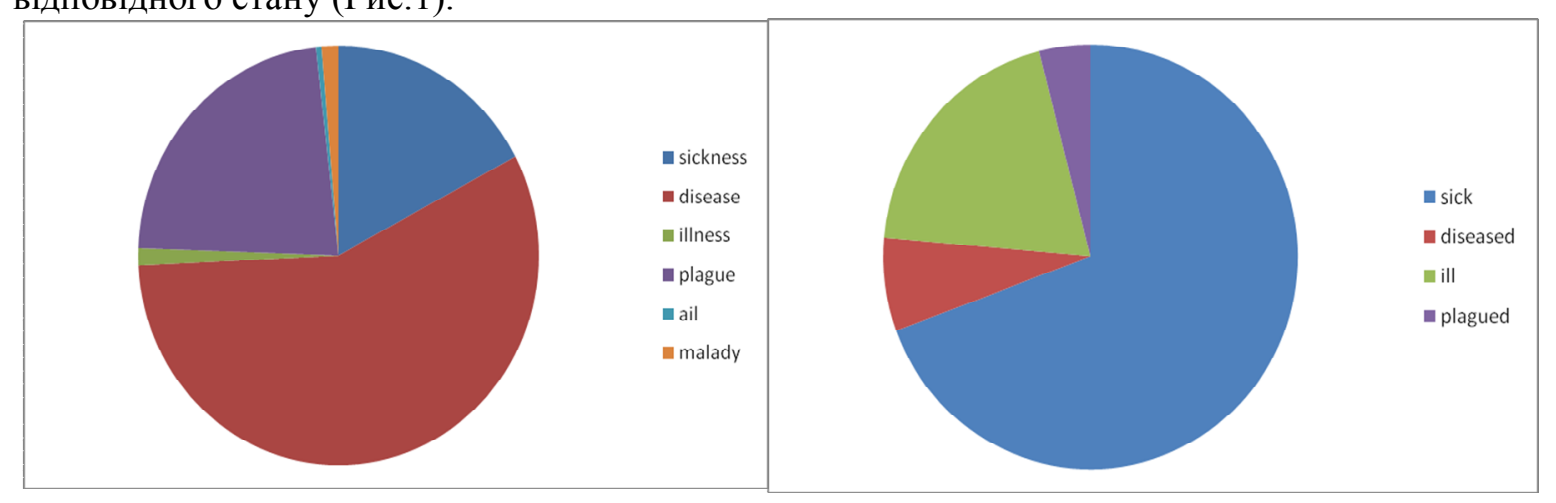

Рис.1. Співвідношення номінацій хвороби і відповідних станів

Так, найбільш поширеними номінаціями власне ХВОРОБИ (процесу клінічного характеру) є disease, а найбільш чисельні номінації "хворобливого стану" (пов'язаного 3 різноманітними сценаріями і контекстами) включають одиницю sick. Частка номінацій ХВОРОБИ у вибірці не перевищує $1 \%$, що свідчить про відсутність домінантного "патологічного забарвлення" саме цього фрагменту семіосфери. Різнорівневі номінативні одиниці, до складу котрих входить певне ім'я ХВОРОБИ, реалізують такі їі семантичні ролі / моделі концептуалізації (цитати з корпусу без вказівки на виконавця) як ХВОРОБА - це:

об'єкт трансляції / трансльований стан: I bring poverty, sickness and death; iron voice causing sickness; Spreading disease and all the madness like dreamscapes; I've really got some vices, the way you spread your disease; Migratory frenzy, the disease begins to spread; Spreading your poison disease Black is the magic, past the insane; In the breeze The disease Breaking out Flying about; Bleeding the lives of the lost Feeding them terminal disease;

слабкість / пошкодження: His body was weak of sickness and old age; Your mind is sickly from Alzheimer's disease, And decadence and debauchery killed your memories;

суб'скт (агенс, каузатор, афліктор): I am your sickness Bitting you; This vile sickness Cut too many down; sickness destroyed his life; Orphans of sickness; Signed by your own sickness; 'Cause from the mud there comes disease A new born hate disturbs the peace; Disease-Inflicting the soon to be born;

суб'скт (сутність, домінатор): Feeling a sickness building inside of me; Sickness fell upon Ligeia; Pathogenic - I spread like a sickness - mad and schizophrenic; A festering sickness that rages inside [також "вміст контейнеру"], spreading like a disease, a cancer-like affliction to bring us down to our knees; infecting like disease - all life below is crushed under the power of machine; I am disease and I'll bring society to it's knees; Disease, disease, disease my friend-for this whole world's in devil's hand;

суб'скт-антагоніст: you are the sickness I am the cure; The grand design of the mother $\underline{W e}$ the disease, and her the cure;

патологічний процес (фізіологічний) / (екологічний - цивілізаційний): The psychological sickness; the sickness I am dying from; In sickness ...In health; Sickness is increasing, as the oceans turn red; Disease, war black death touching man // The human strain, returning plague; Unburied decedents that no longer die Dispelled amok amongst sickness The dead and living are one; filthy teacher's Spreading the disease; All nations hail the end of peace New dawn inception of disease; Some new disease, Some different death; The end of life's immortalized Disease and agony; It's the triumph of shame and disease; Infected with an old disease; 
патологічний процес (негативна оцінка):Torture, murder, necrophilia, sickness of the mind; Killed by Mother's infliction - Psychotropic sickness -There will be no forgiveness; Pure lust is his vice-a sickness to defile; To live on your knees is your own disease;

сенсорне відчуття / емоційний стан: I've found myself in this sickness - feel It's the darkness; A sickness that's known as Pure hate; The fear grows as a sickness uncured;

простір / контейнер: Unexpected relapse into sickness; he depth of your sickness could not be contained; As they once are lost and into the sickness they fall; sickness is your bed; Symposium Of Sickness [на перетині з доменом "якість"];

об'скт протидії / переміщення з контейнера: Incinerate the sickness from this earth; sickness I have left behind; They cut away The sickness Out of all of us; Take this sickness out please; A world of sickness to overcome -We're virus we are a shame; We need a cure for this disease A heeling hand; Now it's time to release our souls from all disease; Cut out the disease The lies and deceit; Disease already left my head; Disease, disease, disease my friend - throw the key or you may die; there ain't no more demons and no more disease - and, mankind, live up, you're free again;

вміст контейнеру: sickness in my heart; The sickness inside of you ...Chasing fear; They're a sickness that's in all our minds;

об'єкт взаємодії: That sickness is my command; Stuffing all we take with us - Madness sickness; it is the sickness that I crave; I want to die Brutally deceased brutally deceased... To die in sickness [контейнер / бажаний простір переміщення];

якість: The sickness of religion is the temple of the dead; Symphonies Of Sickness; A new cureless disease - Another man made religion; they are true death - They are Hate, Despair, Disease

Висновки. Встановлені семантичні ознаки імен концепту ХВОРОБА засвідчують, що цей феномен $\epsilon$ своєрідною універсалією у індоєвропейських лінгвокультурах: низка типологічних паралелей реалізують уявлення про негативно оцінювані в ході "автодіагностики" або оцінки зовнішньою системою структурні та функційні викривлення в архітектоніці біовітальних систем. Глибинні універсальні смисли "втрата енергоємності" і "структурне викривлення", як причини надмірного рівня ентропії, дисфункції та потенційної анігіляції системи, пов'язуються передовсім із зовнішнім шкідливим впливом, що зумовлюють виключно "зовнішні" стратегічні підходи до розуміння причин, профілактики й терапії захворювань. У свою чергу, зміст концепту хвороба постає інтерпретаційним оператором, крізь призму котрого концептуалізуються різноманітні кризові явища соціального буття. Перспективним $\epsilon$ зіставне дослідження номінацій хвороб у різних типах і жанрах дискурсу.

\section{БІБЛІОГРАФІЯ}

1. (ЕСУМ) Етимологічний словник української мови: В 7 томах. Укл. Болдирєв Р. В. та ін. - К.: Наукова думка, $1982-2006$.

2. Колесник О.С. Лінгвокультурні та лінгвосеміотичні особливості вербалізації концепту-міфологеми вогонь // Мовні та концептуальні картини світу. - Вип. 41. - Ч. 1. - К. : Київський університет, 2013. - С. 219 - 227.

3. Колесник О.C. Introducing M-logic: basic remarks on key concepts. Теоретична і дидактична філологія. Серія "Філологія". Серія "Педагогіка". -Вип. 25. - Переяслав-Хмельницький: ПП Щербатих О.В., 2017. - С. 159-169.

4. Левицкий В. В. Этимологический словарь германских языков. / В. В. Левицкий. - Винница: Нова книга, 2010. - T.1. $-610 \mathrm{c}$. $-848 \mathrm{c}$

5. Патофизиология / под ред. В.В. Новицкого, Е.Д. Гольдберга, О.И. Уразовой: ГЭОТАР-Медиа, 2009. - Т. 1.

6. Фасмер М. Этимологический словарь русского языка / М. Фасмер; [пер. с нем. и доп. О.Н Трубачева] : В 4-х т. - М. : Прогресс, 1964. - 1973. $239 \mathrm{c}$.

7. (ЭССЯ) Этимологический словарь славянских языков / ред. Трубачев О.Н. . - Т. 2. М.: "Наука", 1975. -

8. Annihilator. Never // Remains, 1997. - режим доступу http://www.darklyrics.com/lyrics/annihilator/remains.html\#1

9. AntConc Homepage. - режим доступу : https://www.laurenceanthony.net/software/antconc/

10. Bathory. The Land) // Nordland II, 2003. - режим доступу http://www.darklyrics.com/lyrics/bathory/nordlandii.html\#1

11. Beowulf. - режим доступу : http://www.sacred-texts.com/neu/ascp/a04_01.htm

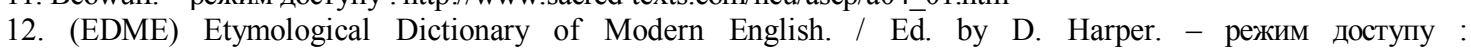
http://www.etymonline.com 
13. Ehrenkranz,N. J, Sampson, D.A. Origin of the Old Testament Plagues: Explications and Implications / N. Joel

Ehrenkranz,Deborah A. Sampson. // Yale Journal of Biology and Medicine. - 2008. - \# 81(1). - PP. 31-42.

14. Guðrúnarkviða in forna. - режим доступу : http://norroen.info/src/edda/gudrun2/

15. Havamál. - режим доступу : http://norroen.info/src/edda/havamal/

16. Hofmann J.B. Etymologisches Wörterbuch des Greichischen. - München: Verlag von R. Oldenbourg, 1950. $543 \mathrm{p}$.

17. In Extremo. Vollmond // Sünder Ohne Zügel, 2001. - режим доступу http://www.darklyrics.com/lyrics/inextremo/snderohnezgel.html\#6
18. Iron Savior. Flesh // Megatropolis,
2007.
режим
доступу

http://www.darklyrics.com/lyrics/ironsavior/megatropolis.html\#1

19. Jamet, D. The Neological Functions of Disease Euphemisms in English and French: Verbal Hygiene or Speech

Pathology? / Denis Jamet // Lexis - Journal in English lexicology. - 2018. - \#12 : https://journals.openedition.org/lexis/2397 $794 \mathrm{p}$.

20. Kroonen G. Etymological Dictionary of Proto-Germanic. / Ed. by A. Lubotsky. - Leiden-Boston: Brill, 2013. -

21. Liberman A.An analytic dictionary of English etymology : an introduction / Anatoly Liberman ; with the assistance of J. Lawrence Mitchell. - Minneapolis, London : University of Minnesota Press, 2008. - 363p.

22. McBain A. An Etymological Dictionary of the Gaelic Language / A. McBain. - Stirling: Eneas MacKay, 1911. $426 \mathrm{p}$.

23. Mooney, J. The Medical Mythology of Ireland / James Mooney // Proceedings of the American Philosophical Society. - Vol. 24. - No. 125. -1887. - pp. 136-166.

24. (MVMI) The Myth of Violence and Mental Illness. Canadian Mental health Association. - Durham. - режим доступу : https://cmhadurham.ca/finding-help/the-myth-of-violence-and-mental-illness/

25. Nibelungenlied, Das. - Stuttgart : Philipp Reclam, 2004.- 1045 S.

26. Ó Ceallaigh, L.B., Kelly, A. Revenants, Retroviruses, and Religion: How Viruses and Disease Created Cultural Mythology and Shaped Religious Perspectives / L.B. Ó Ceallaigh, Andrew Kelly. - Kindle Books, 2019. -297 p.

27. Pokorny J. Indogermanisches etymologisches Wörterbuch / Julius Pokorny. - Bd. 1-2. -Bern: Francke.- 1959. -

1183 S.22.

28. Rammstein. Mutter // Mutter, 2001. - режим доступу : https://www.azlyrics.com/lyrics/rammstein/mutter.html

29. Rowling, J. K. Harry Potter and the Order of the Phoenix / J. K. Rowling. - N.Y. : Scholastic, 2004. - 875 p.

30. Shakespeare, W. Romeo and Juliet / William Shakespeare ; fully annotated,with an introduction by Burton

Raffel. - New Haven and London: Yale University Press, $2004-222$ p.

31. Sigrdrífumál. - режим доступу : http://norroen.info/src/edda/sigrdrif/

32. Tagarelli, A., Tagarelli, G. et al. Greek and Roman Myths Recognized in Naming Syphilis / Antonio Tagarelli, Giuseppe Tagarelli et al. // JAMA Dermatology. - 2011. -147(11). p. 1316.

33. Trompoukis, C., Kourkoutas, D. Greek mythology: The eye, ophthalmology, eye disease, and blindness /

Constantinos Trompoukis, Dimitrios Kourkoutas // Canadian Journal of Ophthalmology. -2007. - 42(3). - pp. 455-459.

34. Vries de, J. Altnordisches etymologisches Wörterbuch / Jan de Vries.- Leiden : Brill, 1962. - 686 S.

35. Vulgate Bible. - режим доступу : https://www.sacred-texts.com/bib/vul/index.htm

36. (Wt) Wæterælfadle. - режим доступу: $h$ ttp://www.sacred-texts.com/neu/ascp/a43_07.htm

37. (WD:) Wið dweorh. - режим доступу : http://colecizj.easyvserver.com/porodch $3 . h t m$

\section{REFERENCES}

1. (ESUM) (1982 - 2006). Etymolohichnyi slovnyk ukrayinskyi movy [Etymological dictionary of the Ukrainian language]. Boldyrev R.B., ed. In 7 vol. Kyiv: Naukova dumka.

2. Kolesnyk, O.S. (2013). Linhvokulturni ta linhvosemiotychni osoblyvosti verbalizatsiyi kontseptu-mifolohemy VOHON [Linguocultural and linguo-semiotic peculiarities of verbalizing the mythic concept of FIRE]. Movni ta kontseptualni kartyny svitu. 41(1). K.: Kyiv university, pp. 219 - 227.

3. Kolesnyk, O.S. (2017). Introducing M-logic: basic remarks on key concepts. Teoretychna I dydaktychna filologiya. "Filologiya". "pedagogika". Issue. 25. Pereyaslav-Hmelnytskyi: Shcherbatyh O.V. pp. 159-169.

4. Levitskiy, V.V. (2010). Etimologicheskiy slovar germanskih yazykov [Etymological dictionary of Germanic languages].Vinnitsa: Nova Knyha. V.1, 610 p.

5. Patofiziologiya [Pathological physiology]. Novitskiy V.V. et al, eds. GEOTAR-media, 2009. Vol. 1. 848 p.

6. Fasmer M. (1964-1973). Etimologicheskiy slovar russkogo yazyka [Etymological dictionary of Russian]. M.: Progress.

7. (ESSY) Etimologicheskiy slovar slavianskih yazykov [Etymological dictionary of Slavic languages]. Vol 2. M.: Nauka,

1975. $239 \mathrm{c}$.

8. Annihilator (1997). Never. Remains. URL: http://www.darklyrics.com/lyrics/annihilator/remains.html\#1

9. AntConc Homepage: URL: https://www.laurenceanthony.net/software/antconc/

10. Bathory (2003). The Land. Nordland II. URL: http://www.darklyrics.com/lyrics/bathory/nordlandii.html\#1

11. Beowulf. URL: http:/www.sacred-texts.com/neu/ascp/a04_01.htm

12. (EDME) Etymological Dictionary of Modern English. Ed. by D. Harper. URL: http://www.etymonline.com

13. Ehrenkranz, N. J, Sampson, D.A. (2008). Origin of the Old Testament Plagues: Explications and Implications. Yale

Journal of Biology and Medicine. 81(1). pp. 31-42.

14. Guðrúnarkviða in forna. URL: http://norroen.info/src/edda/gudrun2/

15. Havamál. URL: http://norroen.info/src/edda/havamal/

16. Hofmann, J.B. (1950). Etymologisches Wörterbuch des Greichischen. München: Verlag von R. Oldenbourg, 543 p. 
17. In Extremo (2001). Vollmond. Sünder Ohne Zügel URL:

http://www.darklyrics.com/lyrics/inextremo/snderohnezgel.html\#6

18. Iron Savior (2007). Flesh. Megatropolis URL: http:/www.darklyrics.com/lyrics/ironsavior/megatropolis.html\#1

19. Jamet, D. (2018) The Neological Functions of Disease Euphemisms in English and French: Verbal Hygiene or

Speech Pathology? Lexis - Journal in English lexicology. 12 URL: https://journals.openedition.org/lexis/2397

20. Kroonen G. (2013). Etymological Dictionary of Proto-Germanic. Ed. by A. Lubotsky. Leiden-Boston: Brill, 794 p.

21. Liberman A. (2008). An analytic dictionary of English etymology : an introduction. Minneapolis, London: University of Minnesota, $363 \mathrm{p}$.

22. McBain A. (1911). An Etymological Dictionary of the Gaelic Language. Stirling: Eneas MacKay, 426 p.

23. Mooney, J. (1887). The Medical Mythology of Ireland Proceedings of the American Philosophical Society. Vol. 24 (125). pp. 136-166.

24. (MVMI) The Myth of Violence and Mental Illness. Canadian Mental health Association. - Durham. URL: https://cmhadurham.ca/finding-help/the-myth-of-violence-and-mental-illness/

25. Nibelungenlied, Das (2004). Stuttgart : Philipp Reclam, 1045 S.

26. Ó Ceallaigh, L.B., Kelly, A. (2019). Revenants, Retroviruses, and Religion: How Viruses and Disease Created Cultural Mythology and Shaped Religious Perspectives. Kindle Books, 2019, 297 p.

27. Pokorny J. (1959). Indogermanisches etymologisches Wörterbuch. Bd. 1-2. Bern: Francke,1183 S.

28. Rammstein (2001). Mutter. Mutter. URL: https://www.azlyrics.com/lyrics/rammstein/mutter.html

29. Rowling, J. K. (2004). Harry Potter and the Order of the Phoenix. N.Y.: Scholastic, 875 p.

30. Shakespeare, W (2004). Romeo and Juliet. New Haven and London: Yale University Press, 222 p.

31. Sigrdrífumál. URL: http://norroen.info/src/edda/sigrdrif/

32. Tagarelli, A., Tagarelli, G. et al. (2011). Greek and Roman Myths Recognized in Naming Syphilis. JAMA Dermatology. 147(11). p 1316.

33. Trompoukis, C., Kourkoutas, D. (2007). Greek mythology: The eye, ophthalmology, eye disease, and blindness. Canadian Journal of Ophthalmology. 42(3). pp. 455-459.

34. Vries de, J. (1962). Altnordisches etymologisches Wörterbuch. Leiden: Brill, 686 S.

35. Vulgate Bible. URL : https://www.sacred-texts.com/bib/vul/index.htm

36. (Wt) Wæterælfadle URL : http://www.sacred-texts.com/neu/ascp/a43_07.htm

37. (WD:) Wið dweorh. URL : http://colecizj.easyvserver.com/porodch33.htm

\title{
ВІДОМОСТІ ПРО АВТОРА
}

Олександр Колесник - доктор філологічних наук, професор, професор кафедри германської філології Київського університету ім. Б. Грінченка.

Наукові інтереси: лінгвосеміотика, лінгвокультурологія, когнітивні студії, міфологія.

INFORMATION ABOUT THE AUTHOR

Oleksandr Kolesnyk - Doctor of Philology, Professor, Professor of Germanic philology chair, Kyiv Borys Grinchenko University.

Scientific interests: semiotics, linguo-cultural studies, cognitive sciences, mythology.

\section{УДК 811.111 \\ DOI: 10.36550/2522-4077-2021-1-193-321-326} ATTITUDINAL PSEUDO-CLAUSES IN DISCOURSE

\author{
Valery MYKHAYLENKO (Ivano-Frankivsk, Ukraine) \\ ORCID.org/0000-0003-3763-7156 \\ e-mail: valerymykhaylenko@i.ua
}

МИХАЙЛЕНКО Валерій. ПСЕВДОРЕЧЕННЯ АВТОРСЬКОГО ВІДНОШЕННЯ У ДИСКУРСІ. У роботі розглядаються проблеми зниження ймовірності мовия в дискурсі та розкриття його засобів вираження. Дослідження об'єктивних висловлювань у різних регістрах дискурсу з використанням лінгвістичної категорії модальності дає змогу вирізнити кореляцію хеджування та типу модальності, щьо потрактована як аспект міжособистісної метафункиії мовної компетентності (Aитӥller, 2014). Термін "модальність" поділяє иілий ряд понять у галузях філософії, морфології, синтаксису, семантики та аналізу дискурсу. Дослідження модальності як міжсособистісної метафункиії в системній функиіональній лінгвістиці в літературі головним чином зосереджувались на варіантах жанрів та / або дискурсу, а саме; консервативний, юридичний, медіа, літературний, академічний, політичний та медичний, а також в живання сучасне англійської мови (Jеspersen, 1924). Дана стаття продовжує авторську серію про хеджування в дискурсі (Mykhaylenko, 2017). Дискурсна 